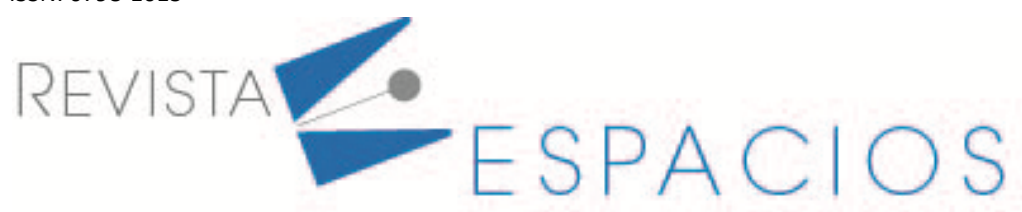

\title{
Web 2.0 Tools: A mediation in the teaching and learning process of mathematics and physics in higher education
}

\section{Herramientas Web 2.0: Una mediación en los procesos de enseñanza y aprendizaje de las matemáticas y la física en la Educación Superior}

\author{
PRADA-NÚÑEZ, Raúl ${ }^{1}$ \\ HERNÁNDEZ-SUAREZ, César A. ${ }^{2}$ \\ PAZ-MONTES, Luisa S. ${ }^{3}$
}

\begin{abstract}
The objective was to design a didactic experience that would facilitate the processes of teaching and learning of functions in the students of a public university. A quantitative approach is adopted at the descriptive level. The questionnaire is used as an instrument. As a result, it was found that the activities implemented facilitated the learning of mathematics applied to physics. The contributions are concluded as positive since the students were able to focus on specific aspects of the selected lessons applying physical reasoning by means of the Web 2.0 resource.

key words: google classroom, higher education, physical math.

\section{Resumen}

El objetivo era diseñar una experiencia didáctica que facilitara los procesos de enseñanza y aprendizaje de funciones en los estudiantes de una universidad pública. Se adopta un enfoque cuantitativo a nivel descriptivo. Se utiliza el cuestionario como instrumento. Como resultado, se encontró que las actividades implementadas facilitaron el aprendizaje de las matemáticas aplicadas a la física. Se concluye como positivas las contribuciones puesto que los estudiantes pudieron centrarse en aspectos específicos de las lecciones seleccionadas aplicando el razonamiento físico por medio del recurso de la Web 2.0.
\end{abstract}

Palabras clave: google classroom, educación superior, matemática física.

\section{Introduction}

The use of technological tools in academic activities responds to current needs in a new social and technological context that has its natural space on the Internet (Duart \& Lupiáñez, 2005), which support the processes of teaching and learning. In addition, they open a range of possibilities of use that can be situated both in the field of distance education, as well as in that of modalities of face-to-face teaching (Salinas, 2008; Rizales-Semprum, Gómez-Valderrama \& Hernández-Suarez, 2019). Although, in the contexts or educational environments that mediate the ICT, the quality of the teacher-student-learning content interactivity is required, and more

\footnotetext{
${ }^{1}$ Teaching research. Faculty Education, Art and Humanities. Francisco of Paula Santander University. raulprada@ufps.edu.co

2 Teaching research. Faculty Education, Art and Humanities. Francisco of Paula Santander University. cesaraugusto@ufps.edu.co

${ }^{3}$ Teaching research. Business Faculty. Francisco of Paula Santander University. luisastellapm@ufps.edu.co
} 
specifically, for the quality of the educational aids that are developed to support, guide and guide the constructive activity of the student to appropriate the contents (Barberà et al., 2004). That is, the mediation in virtual environment (Prada, Hernández \& Gamboa, 2019).

Mediation in the virtual context has the advantage of favouring interactive meetings with a longer duration, allowing a more fluid and orderly dialogue and avoiding the interruptions that are generated when a face-toface session exceeds a certain number of attendees and makes it more flexible (Amaro, 2010). From our perspective, in a world connected to the Internet, it is necessary to mediate in different types of technological systems also called Virtual Learning Environments (VLE) (Guaña-Moya, Llumiquinga-Quispe, \& Ortiz-Remache, 2015; Albarracín, Hernández \& Rojas, 2020), which are very varied platforms, free and paid. They are available as Moodle, Edmodo, Google Classroom, among others. All these systems allow various forms of interaction between the actors of the didactic act and offer the teacher multiple possibilities of management of their practice, in areas such as mathematics and physics as strategies to motivate their students. Generally, students are unmotivated to learn these areas, they require not only to see mathematical contents as operations and calculations, but they must develop their logical and abstract thinking and associate them with a universal language for the development of knowledge - in a positive way with the use of technological tools (Cuicas, Debel, Casadei, \& Álvarez, 2011).

For this reason, research has been oriented in the international context on the use of current technological tools (Tous \& Zapata, 2011). On the other hand, ICTs have been incorporated into the teaching-learning process to promote the development of basic cognitive skills of the student through the use of Moodle working platform in a Blended Learning (BL) class for the Physics I subject (Sanabria, 2012). Also, the use for task management and as a communication tool between students and teachers in the implementation of the virtual platform Google Classroom has been valued (Moya et al., 2017). Likewise, Google Classroom environments are effective in collaborative learning in solving mathematical problems (González-Sastre, 2017). At a national level, it is worth mentioning studies about virtual learning environments as a pedagogical strategy for the development of the competence and comprehensive use of scientific knowledge in the teaching of natural sciences such as Physics (Hernández \& Pulido, 2019) and maths (Albarracín, Hernández \& Rojas, 2020).

Also, it has been important to provide students and teachers with relevant learning for an information and knowledge society that stimulates their resources using technological tools (Hernández, 2017). So, in the field of teaching, it offers a space that uses diverse content in different formats (text, audio, sound, video, iconic, etc.) in strategies such as the flipped classroom (Mora \& Hernández, 2017; Hernández-Suárez, Prada-Núñez \& Gamboa-Suárez, 2020). As a resource, it even serves to promote the personal learning networks (Castañeda \& Adell, 2013; Gómez-Valderrama, Hernández-Suárez \& Prada-Núñez, 2020), of the students and to associate connections (Siemens, 2005).

Therefore, this research provides an advance to the scientific field concerning the use of technological platforms such as Google Classroom in teaching. This free tool created by Google offers the possibility of creating new forms of interaction and communication during the didactic act. Also, in the practical aspect, to examine the use of ICT in the mediation of the teaching and learning process of mathematics and physics in higher education. This could lead to changes in teaching, so that the transformations induced by technological developments in education can be faced with solid bases. According to the above, the objective was to design a didactic experience to facilitate the processes of teaching and learning of functions in students at a public university in Colombia.

\subsection{Conceptual framework}

\subsubsection{The teaching experiences}

In the educational process, teaching will depend on the teacher's perspective (Dollar, 2016), as to how the students learn, and the learning theories that help organize the instruction. In this way, to carry out a teaching experience, it must be planned based on both processes, teaching and learning (Woolfolk, 2010). Brousseau 
(1997), points out that in the didactic situations three elements are mainly involved: the student, the teacher and the didactic environment; and it is the teacher who provides the environment in which the student builds his knowledge. Therefore, the teaching situation is the set of interrelations that occur between these elements (teacher-student-teaching environment). These situations are seen here as didactic experiences. The teacher through teaching sets the tone in its design, with the purpose of achieving the desired change in individuals with the development of meaningful learning (Ausubel, 1968).

While in learning, the didactics are based on learning theory. For example, behaviorism laid the foundation of the first educational software with the principles of educational programming to be considered in teaching (Gros, 1997). In cognitivism, learning is conceived as an internal process resulting from the interaction of the individual with his environment, taking as a starting point his cognitive structure and how he performs information processing during his learning. Meanwhile, constructivism, considers the learner as an active entity during his learning process in the construction of knowledge and highlights the importance of the learner's relationships with the situations given in his environment (Woolfolk, 2010).

Didactic experience is understood as a convergence of teachers, students, resources and activities in a natural or virtual ecosystem, among the strategies classified according to the agent that carries out the action in teaching, instructional, learning and evaluation strategies (Feo, 2010).

In relation to didactics, from a Piagetian perspective, all knowledge is built by the constant interaction between the subject and the object of learning, being the contents the basis on which the hierarchization of mental structures is developed (Godino, 2003). Hence, the development of didactic experiences is based on a planned process of instructional design (Agudelo, 2009) a process that includes stages and aspects that depend on the model adopted and the author who proposes it, although the general stages coincide in great part with the instructional models.

The process of instructional design comprises five interrelated stages (Rowntree, 1976): (1) Planning: which depends on the purposes, objectives, characteristics of the students, and their assessment; (2) Design of learning experiences, related to the learning objectives, sequences, contents and means to be used; (3) Experimentation, which is the small-scale testing of what is planned; (4) Review, which responds to the results of the experimentation; (5) Implementation, once reviewed, is put into practice for evaluation, feedback and updating.

\subsubsection{Didactic experience design for teaching mathematics and physics with Google Classroom}

Virtual Learning Objects (VLOs) are new ways of mediating the teaching-learning process. The trend has been to use the board, projectors, digital presentations, study guides, among others. But what is needed is to move towards a concept of using integral OVAs that in the absence of the teacher and in attention to the abstract nature of mathematics and physics, are capable of promoting the interiorization of the contents to the student and generate conditions in which he has to apply them for the understanding of the processes of his profession, through problematization and contextualization. Google Classroom, created for educational purposes, allows integration with other applications developed by Google such as Google Documents, Google Drive, Google Forms and Google Calendar, thus allowing greater effectiveness and efficiency (Vélez, 2016). Hence, this system creates a virtual classroom with resources (documents, videos, links, among others) and activities (forums, tasks, etc.). In addition, this tool is like some Virtual Teaching and Learning Environments (VTLE), therefore, the main objective is to facilitate teachers to manage their classes and improve communication with their students.

On the other hand, the way in which teaching, and learning is done proposes modes of action when designing the didactic experience with technological mediations. In the case of Google Classroom, in our opinion, the design of experiences with technology could propitiate ways of perceiving, reasoning, and interpreting the world of mathematics and physics, different from those proposed in traditional teaching. ICTs promote cooperative 
work, enhance skills such as the ability to appropriate visual stimuli at high speed and the ability to perform different tasks at the same time (Cariaga, 2018). The teaching-learning process of mathematics and physics begins by motivating the student to study this science because of the relationships it has with his professional development. Therefore, the use of the VLOs must be based on your ability to communicate, which ensures that you are motivated to interact with the object to achieve your learning.

Therefore, it is assumed that in the teaching-learning process mediated by the VLOs, there is a multidirectional communication process between the teacher, the students, the VLO, and the VTLE, so that information flows through different channels between each of the parties involved in this process. For this, it is necessary that the VLO complies with the principles of the unity of the affective and cognitive, in addition to the activity and communication as they are pillars in the multidirectional communication.

\section{Methodology}

\subsection{Approach and design}

The research corresponds to a quantitative approach. The level was descriptive, and the path followed was field work.

\subsection{Target population and key informants}

For a better understanding of the use of Google Classroom as a tool that facilitates the teaching and learning processes of mathematics and physics in higher education students, a census-type population was considered for the study. Therefore, we worked with a group of 28 students enrolled in a Bachelor's program in Natural Sciences at a public university who are studying mathematics applied to physics.

\subsection{Procedure}

The design process was carried out according to the instructional design model proposed by Rowntree (1976).

\subsection{Design of learning experiences}

Taking into account the basic principles of design, the experiences that include Google Classroom facilitate the learning of mathematics applied to physics and allow students to separate themselves from the notions about physics being only formulas and mathematics.

The study of physical phenomena begins with the measurement of quantities (lengths, times, speeds, pressures, etc.). In physics there are rules that must be respected (principles or laws) and these rules relate the quantities themselves to one another through a mathematical formula. Mathematics is therefore the language that physics uses to express different events that occur in nature, to express the relationship between the various physical quantities that we can measure when studying natural phenomena. The fact that mathematics is essential in physics should not be confused with the idea that physics is mathematics. The variables in a physical formula do not correspond to abstract objects that are merely mathematical, but represent physical concepts, linked to reality. The result of mathematical calculations must make physical sense.

\section{Results}

\subsection{Training environment: Google classroom}

- Half of the students consider the ease of use offered by Google classroom to be excellent, with an equal weight of $21.43 \%$ considering it to be high and correct. The ease of use offered by Google classroom stands out, as it is perceived by a considerable part $(71.43 \%)$ of students. 
- The presentation of the Google classroom interface in terms of screen design, images and text was rated as high (42.86\%) and excellent (39.29\%), followed by $14.29 \%$ as correct and $3.57 \%$ as low. Most ( 82.15 $\%)$ of the students highlight the design of screens, images, texts that consolidate the presentation of the Google classroom interface.

- The quality of the resources available in Google classroom was high (53.57 \%) and excellent (39.29\%), only for $7.14 \%$ was it correct. Students (92.86\%) consider the quality of the resources available in Google classroom to be high.

- Students considered high (53.57\%) and excellent (35.71\%) the structure of the contents in Google classroom, for $7.14 \%$ it was correct and low for $3.57 \%$. The majority $(87.28 \%)$ of students consider that the structure of the contents in Google classroom stands out.

- $88.89 \%$ thought that interactivity in Google classroom was high (66.67\%) and correct (22.22\%), only $7.41 \%$ considered excellent and $3.7 \%$ low. Student interactivity in the Google classroom for the majority (88.89\%) of students was appropriate.

- The originality of Google classroom was high (46.43\%) and excellent (42.86\%), for $10.71 \%$ it was correct. Students (89.29\%), consider the Google classroom platform innovative.

- About Google classroom the students highlighted how easy it is to use, the possibilities of exchange and interaction with the teacher and the availability of resources at any time. Those expressed by the students correspond to the results of the survey.

\subsection{Teaching plan and pedagogical model}

\subsubsection{Designed experience}

- The programming of activities during the experience was high (57.14 \%) and correct (25\%). 14.29\% considered it excellent and $3.57 \%$ low. The majority (92.14\%) perceive the programming of activities during the experience as adequate.

- The students thought it was high (42.86\%) and correct (39.29\%) the adequacy of the experience to their interests $14.29 \%$ considered it excellent and low $3.57 \%$. Students (82.15\%) perceived that the experience was appropriately tailored to the students' interests was considered.

- The development of the experience for the students was high (50\%) and excellent $(35.71 \%)$ followed by $14.29 \%$ who considered this aspect correct. For the majority $(85.71 \%)$ of the students the experience went well. The students' opinions on this indicator were favourable: the schedule and the experience itself. The opinion expressed by the students corresponds to the quantitative results.

\subsubsection{Learning}

- The promotion of their autonomy to learn was high $(42.86 \%)$ and correct $(28.57 \%)$ and excellent for $21.43 \%$, it was only low for $7.41 \%$. Many students $(71.45 \%)$ perceive that the promotion of their autonomy to learn is adequate.

- Activities to encourage collaborative learning were weighted by students as high (50\%), correct (28.57\%) and excellent (21.43\%). The majority (78.57\%) of students perceive as appropriate the activities to encourage collaborative learning.

- The attractiveness of the activities developed during their learning process was high (57.14\%) and correct $(28.57 \%)$. It is noteworthy that with the same weighting of $7.14 \%$ the students valued this aspect as excellent and very low. A considerable part (85.71\%) of the students found the attractiveness of the activities developed during their learning process adequate. About their learning of functions, the students expressed that the strategy gave them autonomy and facility to learn. Most of the students expressed their satisfaction with the activities proposed for their learning, which is consistent with the results of the questionnaire. 


\subsubsection{Evaluation}

- The assessment of learning achievement for students was high (57.14\%) and correct $25 \%$, and excellent (10.71\%) and low $7.14 \%$. For most students (82.14\%) the assessment of learning achievements was appropriate. Only one of the students expressed the short time available for the elaboration of the proposed activities in Google classroom. Most of the students expressed the relevance of the teaching experience and the proposed activities.

\subsubsection{Teaching role}

- Students weighted as high $(57.14 \%)$ the monitoring of their learning progress, correct (25\%) and excellent (14.29\%). Monitoring of learning progress was appropriate for most students $(82.14 \%)$.

- The activity carried out by the teacher during the experience was excellent (50\%) of the students, $39.29 \%$ considered it high and $7.14 \%$ correct for $3.57 \%$. The students perceived the activity deployed by the teacher as preponderant.

- Tutoring during the experience was rated as excellent (50\%) and high (35.71\%) followed by the $14.29 \%$ who considered it correct. Students feel that the tutoring excelled during the experience.

- As high (39.29\%) and excellent (35.71\%) were assessed the meetings during the experience and $25 \%$ considered them correct. Most (75\%) of the students perceived that the face-to-face meetings stood out during the experience.

- $46.43 \%$ considered that the proposed schedule of activities was high and with an equal weighting of $25 \%$ was rated excellent and correct. The schedule of activities during the development of the experience was relevant for the majority $(71.43 \%)$.

- The role of the teacher was considered by most students as highly positive and favourable to the development of the experience. What the students said is consistent with the results of the survey.

\subsection{Overall assessment of the online course}

- The technical quality was high for half of the students followed by $32.14 \%$ for whom it was excellent, while for $17.86 \%$ it was correct. Most students $(82.14 \%)$ consider Google classroom to have a prominent technical quality.

- The utility of Google classroom was considered by the students, with similar values, as excellent (46.43\%) and high (42.86\%) and $10.71 \%$ thought it was correct. Students (89.29\%) consider that Google classroom stands out for its usefulness.

- It highlights the students' opinion regarding their projection as future teachers and the application of strategies like those experienced as students. There is an emerging aspect related to the projection as future teachers. In general, the didactic experience developed is useful depending on what is expressed by the students. Results are consistent between what students expressed and their opinions in the surveys.

\section{Discussion}

The design and implementation of the didactic experience on functions and their applications in Physics required a planned and implemented phase (Rowntree, 1976), with strategies according to the didactic resources in the Google Classroom platform, to facilitate the teaching and learning process. In this sense, the didactics were the plans that guided the teaching strategy for both processes (Woolfolk, 2010), both in the classroom sessions and in the asynchronous virtual interaction, which would begin to respond to the general objective.

In relation to the Google Classroom Training Environment, it was verified, based on the results obtained, that the Google classroom interface is easy to use, since the interactivity allows an effective and efficient organization of 
contents associated to the Google educational suite (Vélez, 2016). This also allowed the development of the teacher's plan and model and, therefore, the designed experience, in which the students in studies showed an appropriate programming of contents during the strategy, making room for an interaction between the elements of the didactic situation, that is, student, teacher and the didactic environment (Brousseau, 1997).

From there, that same plan and model of the teacher planned in the didactic experience implemented that Google platform, promoted in the students autonomy to learn in an active way (Woolfolk, 2010), through activities that promote collaborative learning in the learning process. In this way, it is achieved that the student acquired aptitudes, abilities and skills when recognizing and manipulating elementary functions of real variable. For this reason, the evaluation of learning achievements for students was adequate.

The role of the teacher was widely highlighted; the findings suggest that students felt supported by the teacher during the development of the experience, since it was executed within the planned process of instructional design (Agudelo, 2009), the management of activities, tutoring, face-to-face meetings, programmed activities and the follow-up of their progress.

Also, it was evidenced that in Google Classroom, students strengthen skills of appropriation of visual stimuli and facilitate different tasks at the same time (Cariaga, 2018), in which it was verified that the mediation in this platform through the programmed forums and the complementary resources managed to understand in a $82.14 \%$ the thematic approached on functions

\section{Conclusions}

It is concluded that the experience in Google Classroom was relevant and was widely highlighted as support in the process of teaching physics and mathematics. As well as, to the learning process. Since, it allowed the students to work at a pace adjustable to their learning and to know how to do complicated mathematical calculations to solve physics problems, with the support of attractive and interactive media provided and the tutoring of the teacher. In this, Google Classroom experience not only allowed students to learn at their own pace, but the teacher was better able to provide individualized instruction to each student. Similarly, it was evident in this experience that students could have the ability to focus on specific aspects of the selected lessons and content provided in Google Classroom by applying physical reasoning, i.e., knowing where and how to use the different principles and fundamental laws of physics, which resulted in students performing and interacting in more participatory activities in the classroom, therefore, students in the Bachelor of Science program in natural sciences obtained better results in their classes.

\section{Bibliographic references}

Agudelo, M. (2009). Importancia del diseño instruccional en ambientes virtuales de aprendizaje. En J. Sánchez (Ed., Nuevas Ideas en Informática Educativa (pp. 118-127). Santiago de Chile: Universidad de Chile.

Albarracín, C., Hernández, C., \& Rojas, J. (2020). Objeto virtual de aprendizaje para desarrollar las habilidades numéricas: una experiencia con estudiantes de educación básica. Panorama, 14(26), 111-133. http://dx.doi.org/10.15765/pnrm.v14i26.1486

Amaro, R. (2010). La mediación didáctica en entornos virtuales. Revista de Artes y Humanidades UNICA, 11(3), 156-173.

Ausubel, D. (1968). Educational Psychology: A Cognitive View. New York: Holt, Rinehart \& Winston.

Barberà, E., Badia, A., Colomina, R., Coll, C., Espasa, A., De Gispertet, I., ... Sigalés, C. (2004). Pautas para el análisis de la intervención en entornos de aprendizaje virtual: dimensiones relevantes e instrumentos de evaluación. Recuperado de https://www.uoc.edu/in3/dt/esp/barbera0704.pdf 
Brousseau, G. (1997). Theory of Didactical Situations in Mathematics. Dordretch: Kluwer.

Cariaga, R. (2018). Experiencias en el uso de las TIC. Análisis de relatos de docentes. Ciencia, Docencia y Tecnología, 29(56), 131-155.

Castañeda, L., \& Adell, J. (2013). Entornos Personales de Aprendizaje: claves para el ecosistema educativo en red. Alcoy, España: Marfil.

Cuicas, M., Debel, E., Casadei, L., \& Álvarez, Z. (2011). El software matemático como herramienta para el desarrollo de habilidades del pensamiento y mejoramiento del aprendizaje de las matemáticas. Revista Electrónica Actualidades Investigativas en Educación, 7(2), 1-34.

Dollar, D. (2016). Book Review: Five Perspectives on Teaching in Adult and Higher Education. California: Sage Publications.

Duart, J., \&Lupiáñez, F. (2005). Estrategias en la introducción y uso de las TIC en la universidad. Revista de Universidad y Sociedad del Conocimiento, 2(1), 5-31.

Feo, R. (2010). Orientaciones básicas para el diseño de estrategias didácticas. Revista electrónica Tendencias Pedagógicas, 16, 221-236.

Godino, J. (2003). Perspectivas de la Didáctica de las Matemáticas como disciplina científica. Universidad de Granada.

Gómez-Valderrama, C., Hernández-Suárez, C. \& Prada-Núñez, R. (2020). La zona de posibilidades en el proceso de aprendiencia del residente digital: un análisis cualitativo en la red de experiencias matemáticas de Norte de Santander. Educación y Humanismo, 22(38), 1-19. https://doi.org/10.17081/eduhum.22.38.3688

González-Sastre, M. A. (2017). Aprendizaje colaborativo en la resolución de problemas matemáticos en entornos Google Classroom (tesis maestría). Universidad Internacional de la Rioja, La Coruña, España.

Gros, B. (1997). Diseño y programas educativos. Pautas pedagógicas para la elaboración de software. Barcelona: Ariel Educación.

Guaña-Moya, E. J., Llumiquinga-Quispe, S., \& Ortiz-Remache, K. J. (2015). Caracterización de entornos virtuales de enseñanza aprendizaje (EVEA) en la educación virtual. Ciencias Holguín, 21(4), 1-16.

Hernández, L. \& Pulido, C. (2019). Ambientes virtuales de aprendizaje como estrategia pedagógica para el desarrollo de la competencia uso comprensivo del conocimiento científico en la enseñanza de las ciencias naturales (tesis maestría). Universidad de la Costa, Barranquilla, Colombia.

Hernández, R. (2017). Impacto de las TIC en la educación: Retos y Perspectivas. Propósitos y Representaciones, 5(1), 325-347.

Hernández-Suárez, C. A., Prada-Núñez, R., \& Gamboa-Suárez, A. A. (2020). Formación inicial de maestros: escenarios activos desde una perspectiva del aula invertida. Formación universitaria, 13(5), 213-222. https://dx.doi.org/10.4067/S0718-50062020000500213

Mora, B., \& Hernández, C. (2017). Las aulas invertidas: una estrategia para enseñar y otra forma de aprender física. Inventum, 12(22), 42-51. https://doi.org/10.26620/uniminuto.inventum.12.22.2017.42-51

Moya, M. M., Bia, A., Carrasco, M. M., Jiménez, M. A., Ramón, A., \& Soler, C. (2017) Memoria Red en metodologías docentes con TICS 2016/2017: implementación de la plataforma virtual Google Classroom. En R. Roig-Vila, J. M. Antolí, A. Lledó \& N. Pellí (Eds.), Memorias del Programa de Redes-I3CE De calidad, 
innovación e investigación en docencia universitaria. Convocatoria 2016-17 (pp. 2564-2574). Alicante: Universidad de Alicante.

Prada, R., Hernández, C. A. y Gamboa, A. A. (2019). Usos y efectos de la implementación de una plataforma digital en el proceso de enseñanza de futuros docentes en matemáticas. Revista Virtual Universidad Católica del Norte, (57), 137-156. https://doi.org/10.35575/rvucn.n57a10

Rizales-Semprum, M.J, Gómez-Valderrama, C.L \& Hernández-Suarez, C. A. (2019). Uso de herramientas tecnológicas para la enseñanza de la ciencias en educación media diversificada de acuerdo a la modalidad de estudio a distancia. Eco Matemático, 10 (2), 35-46. https://doi.org/10.22463/17948231.2591

Rowntree, D. (1976). Educational Technology. Londres: Harps and Row Publishers.

Salinas. J. (2008). Innovación educativa y uso de las TIC. Sevilla: Universidad Internacional de Andalucía.

Sanabria, I. (2012). El aprendizaje de física I en entornos tecnológicos. Un modelo de formación Blended Learning basado en el desarrollo de habilidades cognitivas básicas (tesis doctoral). Universitat Rovira i Virgili, Tarragona, España.

Siemens, G. (2005). Connectivism: A learning theory for the digital age. International Journal of Instructional Technology and Distance Learning, 2(1), 3-10.

Tous, C., \& Zapata, N. (2011). El blog en el aula. Relato de una experiencia en la FPyCS-UNLP. I Jornadas Nacionales de TIC e Innovación en el Aula, 1-8.

Vélez, M. (2016). Google Classroom en la enseñanza: Manual sobre las funciones básicas y mejores prácticas de uso. San Juan: Universidad de Puerto Rico.

Woolfolk, A. (2010). Psicología educativa. México: Pearson Educación.

Esta obra está bajo una Licencia Creative Commons

Attribución-NoCommercial 4.0 International

\section{(cc) EY-NO}

